"Vox Patrum" 6/1986/z. 11.

\title{
PATROLOGIA W SEMINARIACH POLSKICH (Uwagi patrologa)*
}

\section{Organizaçja studiów}

WT polskich Wyzszych Seminariach Duchownych patrolog1e wykłada sie na ogól albo po jednej godzinie w clagu dwóch lat, albo po dwie godziny w clagu jednego roku. W pierwszym przypadku jest ona wykładana na kursie II 1 III lub III 1 IV, w drugim zaś przewaznie na kursie II. W kilku seminariach /według mojego rozeznania we dwóch, obowlazuje inny układ godzin. Mo1m zdaniem najlepszy jest warlant plerwszy, gdyz wykładanie całej patrologil na kursie II jest utrudnione przez brak podstawowych pojęć teologicznych u studentów. W wariancie tym w ciagu pierwszego roku wykłada sie zazwyczaj patrologie przednicejskł, w clągu drugiego zaś - ponicejską. Patrologia jest przedmiotem obowiazkowym 1 kończy się egzaminem; studenc1 ponadto otrzymuja często w ciagu roku prace pisemne lub ustne. T niektórych seminariach istnieja wykłady z wybranych zagadnień histori1 dogmatów. Tam, gdzie sie znajduja patrologowie wykwalifikowant, klerycy po II roku moga soble wybrać seminarium patrystyczne /1 lub 2 godziny tygodniowo/, na którym w ciagu trzech lat studión czyta się dzieła ojców/niekiedy w oryginale/, dyskutuje się nad nimi oraz uczy sie metodologil 1 pisania prac patrystycznych; kończy sie ono napisaniem pracy przedstawianej przed egzaminem "ex universa theologian.

\section{Zakres 1 sposób wykładu}

Wykłady sa kursoryczne 1 obejmuja całość patrologil /a nie

\footnotetext{
* Artykul o podobnej treści autor publikuje w przygotowyranym patrystycznym 13 numerze "Bulletin de Salnt-Sulpice" $1987 \mathrm{r}$. Jako Jedna z polskich propozycji.
} 
tylko autorów wybranych/, Jednych seminariach od początku do Bedy 1 Jana Damasoeŕskiego/poz. VIII w./, w Innych zaś do Soboru Chalcedoriskiego/451 r./.Ponlewaz jest rzecza oczywista, ze nie mozna omów16 wszystkioh autorów, wykładowca, obok podstawowych pisarzy/np. Orygenesa, ́́w. Augustyna czy Grzegorza Wlelklego/ oraz sporów/trynitarne, chrystologiczne, o laske/ dobiera sobie autorów zaleznie od ustawienia przez siebie materil. Wazne jest, by student opanowal patrologie jako pewna całość. W wiekszośoi seminariów wykłady nie sa połaczone z ewlczentami, profesorowie jednak, w mare swoich mozliwośc1 1 zawartośc1 bibliotek, moga je uzupełniać lekturą 0jcón 1 o Ojcach, w rózny sposób egzekwowanq. Dodajmy, ze często z okazj1 lektoratón: lacińskiego 1 ewentualnie greckiego, czyta się eragmenty dziel 0jeów w oryginale. Dwa podręczniki wydane po wojnie słuza jako lektura pomocnicza; wielka pomoca są tu równiez antologie patrystyczne, wykorzystywane w rózny sposób.

\section{Cel mykładów patrologi1}

a/ Juz sam termin 0jciec 1 Doktor/nauczyciel/Kościoła stanowia program: nauczyó studentów, by 0jcowie stali się naprawdę ojcami loh wiary, zyola duchowego, działalności duszpasterskiej 1 homiletycznej, jak byli nimi przez setki lat; te zaś okresy, w któryoh sie to działo, okazały sie wielkimi epokami dziejón Kóscioła.

b/ 0jcowie głosili Ewangelię 1 to w sposób skuteczny. Patrologia pokazuje róznorakie sposoby przekazymania Słowa Bozego - róznych czasach 1 okolicznościach, co moze stanowíc wazny element formacj1 duszpasterskiej alumnów.

c/ 0jcowie byl1 nauczycielami teologit nie powydzielanej między rózne specjalizacje - teologil integralnej. Patrologia więc pokazuje, jak wykładać naukę Bożz całościowo.

d/ Teologia Ojcóm była teologia biblijną, opartą na Piśme śn. Jako całości, mówiącym o Jezusie Chrystusie. Uczą nas więc całościovego pojmowania Pisma Sw., przemodlonego oraz odczytywanego rezumem 1 sercem.

e/ Ojoowie byl1 śmiadkami wiary Kościoła jeszcze nie podzielonego; pozostaja więc dla nas śviadkami uprzywilejowanymi, szozególnie dialogu ekumenteznym. Nalezy więc pokazać, w jaki sposób pełnili oni role świadków oraz jak wyglądała przekazana 
przez nich tradycja.

f/ ojcowie pozostaja modelem teologa: byll oni bowiem b1skupam1, a wį̨c duszpasterzami, teologami, świętymi, niejednokrotnie mistykami; umieli harmonijnie połączyé głęboką znajomośc teologi1 zwiazanej ściśle z lch zadantami duszpasterskimi, intensywnym życiem modlitwy 1 gorliwym zaangażowantem duszpasterskim.

g/ Patrologia powinna nauczyć, Jaki stosunek zachodzi pomi ̨̧dzy Tradycją a zmianą wościele, Inaczej mówiąc, elementem statycznym 1 dynamicznym. Uczy więc rozumieć tajemnicę Kościoła jako organizmu zywego 1 rozwijajacego się, ale clągle tego samego. Jak waźna jest rzecza uświadomiente sobie tego, jest fakt, ze zarówno tradycjonalizm, jak 1 progresizm wynikają z niezrozumienia tego stosunku: tradycjonalizm - bo nie rozumie aspektu dynamicznego Kośc1o3a, progresizm - elementu statycznego. Innymi słowy: patrologia uczy myślenia historycznego w różnych dziedzinach teologi1: w dogmatyce, moralnośc1, liturgi1, prawie 1td.

To wyliczenie prawdopodobnie niekompletne wskazuje, ze patrologla jest nie tylko przedmiotem, którego sie nauczy, ale moze stanowid wazny element formacyjny. Podczas wykładów trzeba więc nie tylko uczyć zyclorysów oraz mprowadzać dzieła 1 teologi z ojców, ale takze wedle $1 \mathrm{ch}$ wzorów uczyć zyć 1 korzystać z $1 \mathrm{ch}$ dz1eł.

\section{Metoda}

Tego rodzaju ustawienie patrologil wymaga wielopłaszczyznowego programu, który by wskazywał na róźne elementy teologi1, nie zapominając jednak, ze patrologia ma równiez przedstawić postacie 1 zyciorysy ojcótr. By pokazać, jak moźna progran realizować, podam k1lka przykładóv. Przy okazji omawiania ojców Apostolskich mozna próboivać przedstawić, jaka była problematyka pierwszego pokolenia chrześcijan 1 Jak Ja on rozwizzywall majzc do dyspozycji tylko Stary Testament 1 Tradycjo nauki Jezusa Chrystusa; omawiajac Apologetow - pokazać, jak chrześcijaństwo wchodzi w świat kultury helleńskiej; przy Hipolicic - Jak po Vaticanum II dokonywano reformy 11turgicznej/prex eucharistica II/; przy Grzegorzu z Nyssy - Jak powstawała mistyka chrześcijańska 1 jej terminologia/np. porównać ze 6́w. Janem od Krzyża/; na zakończenie omawiania sporów chrystologicznych mozna pokazać, Jak powstały Kościoły Ischodu Chrześcijańskiego 
1td. Tego rodzaju ujęcle pozwala ukazá przy omawianiu poszczególnych pisarzy ozy grup pisarzy, Jak formowała sie kultura chrześcijaraka /w bardzo szerokin tego słowa znaczeniu/. Przy omawianiu wielkich plsarzy, po podaniu wiadomośol ogólnych o loh zyciu i dzielaoh, mozna omówié jeden aspekt loh dziazalnośc1: np. przy św. Augustynie w jednym roku szerzej omów1ó zagadnienia laski, w drugim teologil historil, w trzecim - zycia zakonnego itd.; przy Janio Chryzoston1e: raz nauke o Eucharyst11, 1nnym razem poglądy egzegetyozne lub wychowaweze. Warto równiez pamietá́ o aspekcie artystycznym: wykazá́ walory prozy św. Augustyna, p1ękno hymnów bizantyriskich, greokich homilil maryjnych lub poezji fllozoficznej Boecjusza.

\section{Interdyscyplinarność}

Nalezy pamiętá, ze patrologia jest tylko w pewnym stopniu nauka samo1stną, gdyz powinna ona równiez spełniad funkcje "usługowe" - Etosunku do Innych dyscyplin teologicznych, to znaczy pomagad - zrosunioniu aspektu historyeznego teologil dogmatycznej, moralnej, ascetyki, prawa, liturgi1, egzegezy 1td. Z tego wynka, ze profesor patrologil powinien nawiazać kontakty zrofesorami innych dziedzin 1 stará sie spełniá loh zapotrzeboranie mej dziedzinie. Jeśl1 chodz1 o wykonanie praktyczne tego aspektu, jest ono niestety bardzo trudne do sreal1zowania $\mid$ Polsoe, ze względu na brak tradycj1 patrystyoznej 1 studi6w nad Tradyoja, z czego wynika brak zainteresowania teologón dla aspektu historycznego $1 \mathrm{ch}$ dziedzin. Patrolog powinien równiez nawiazać kontakt z lektoram1, szczególn1e Jezzyków starozytnyoh, 1 "zamawiac" u nich "przerobienie" pewnych tekstów ojé́w.

\section{Niebezpieczeństwa}

a/ Zrobienie z patrologil katalogu pisarzy, 1ch dziez, herezj1 1 problemów teologicznych.

b/ Zrobienie z niej zbioru anegdot 1 opowiadan /chocby budujących/ o 0jcach 1 pisarzach kościelnych, pomijajac wielkie probleny teologiczne $1 \mathrm{ch}$ uwarunkowania /w szerokim słowa znaozeniu/.

c/ Zredukowanie jej do zestawu problemów teologicznych z pominiegem elementu biograficznego czy zrobienie z niej tylko hietori1 dogmat6w.

d/ Ograniozenie jej do zestawu cytatów potwierdzających dane 
prawdy wiary lub sentenoji dla kaznodziejów.

e/ Oderwanie patrologil od dztel 1 zredukowanie jef do wyłącznego omawiania pism nie dopuszczając do głosu samych ojców.

\section{T. Wyk zad owcy}

Jest rzecza oczywista, ze wykładowca zajmuje pozycje kluczowa * nauczaniu patrologi1, poniewaz nawet najlepszy program moze on zepsud, a najgorszy ozywić. Patrolog powinien mieć wykształcenie zarówno humanistyczne / f1lologia klasyczna, orientalna, historia starozytna, archeologia starozytna/, jak i teologiczne/najlepiej patrologia, ale takze jedna z dziedzin teologicznych o profilu historycznym oraz historia Kościoła/. Patrologia jest bowiem dziedziną historyczno-teologiczną, a wykładorca jej powinien nie tylko móc czytać teksty w oryginale, ale także umieć je wyjaśnić teologicznie. Obydwa te elementy: filologiczno-historyczny i teologiczny, powinny współistnied w jak największej harmonil 1 równowadze. Optymalna jest sytuacja, gdy wykładorca sam prowadzi badania naukowe w swojej dziedzinie. W kazdym jednak wypadku powinten on znać dzieła ojców, obcowad z nimi 1 orientować sie w kierunkach rozwojowych patrologi1 współczesnej. Pewien kontakt z duszpasterstwem/na tyle jednak, by go nis odrywal od pracy badawczo-dydaktycznej/, pozwoll mu na odkryc1e tych elementó u 0jcór, które do dziś stanowia lch zywa wartość duszpasterska. Liczba patrologów wykwalifikowanych w polskich seminariach zwizksza s1e, ale bardzo wolno, 1 daleko jest jeszcze do stanu zadowalającego - Kilku księzy studiuje w kzymie, głórnie na Salesianum 1 Augustinianum, natomiast pravie nie wykorzystane pozostaJą mozlimości studiów krajowych, szczególnie na ATK 1 KUL-u. Tam, gdzie nie ma patrologóf, zajłcia z tego przedmiotu prowadza przewaznie dogmatycy 1 historycy. Patrologowie zorganizonani sa w specjalnq sekcje, która co roku odbywa swoje spotkanie w różnych seminariach polskich: pozwalaja one na wymianę osiłgnięć naukowych 1 dydaktycznych, w zwiazzku z czym odgrywajz one wazna role w polskim zyciu patrologicznym.

\section{Odbiór}

Według relacji wykładowców patrologil, odbiór studentón jest na ogół dobry. Powodem tego stanu jest być moze powszechne zainte- 
resowanie światem starożytnym, mimo zniesienia lub ograntczenia nauk1 Języków klasycznych w szkołach średnich. Istnieje ponadto pewne zainteresowante korzeniami wasnej 1dentycznośc1. Na zainteresowanie to wpłynęzy bez watpienia również reformy Kościoła po Vaticanum II, które stawiaja pytanie o mechanizmy przemian 1 stawiają clągłe "dlaczego" w dzledzinie liturgii, prawa, teolog11. Ponadto kontakty ekumeniczne oraz zainteresowante teologia zycia duchowego, szczególnie Wschodu, zachęcaja młodych do czytania ojców. Wszystko więc, co dotyczy Ojców Koścloła /przekłady, antologie, nawet prace naukowe/ znika błyskawicznie z półek ksiegarskich. Teksty 0jców bywają wykorzystywane w duszpasterstwie, szczególnie w grupach modlitewnych. Mniejsze zainteresowanie natomiast znajduJą w kołach teologicznych.

\section{Pomoce nauk owe}

a/ Biblioteka. Powinny się na nią składać trzy rodzaje ksiegozbiorów:

- Podręczna, zawierająca lekturę uzupełniająca do wykładów, a więo przekłady 1 dzieła popularnonaukowe odpowiedniej llości. Wedle zawartości tej biblioteki nalezy przygotomać wykaz lektur.

- Biblioteka specjallstyczna dla uczęszczajz̨cych na seminaria naukowe z patrologii oraz dla profesorów seminarium. Zawierać ona powinna: podstawowe serie wydań tekstów oraz przekładów, najwaźniejsze słowniki 1 encyklopedie, opracowania z historil literatury

1 teologii.

- Księgozbiór profesora, dobierany wedle jego specjalności. Stan bibliotek seminaryjnych jest daleki od stanu zadowalajace go, a szczególnie źle przedstawia się ich zawartość patrologiczna. Serię POK przed wojna prenumerowało zaledwie kilka seminariów /odsyłam do listy załączonej w tomie 19/, a równiez PSP nie prenumeruja, - 1le mi wiadomo, wszystkie seminaria duchowne. Oszcządności w budzetach powoduja brak wystarczajzcej liczby egzemplarzy, by móc zadawać lekture. Brak jest powszechnie wielkich wydań tekstów patrystycznych /Jak PL czy PG, nie múwiąc juz o GCS, CSEL, SCh czy PO/. Stan bibl1otek jest niewatpliwie odzwierciedieniem stosunku da patrologil w ogóle, chod trzeba przyznać, ze w marę przybywania patrologów kwalifikowanych, stan ten sie zwolna polepsza. Sam bowiem wykładowca patro- 


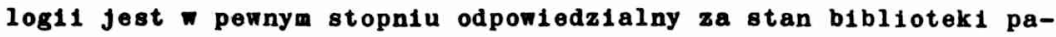
trystyoznej 1 działu patrystyoznego czytelni. Do niego równiez nalezy obowlazek 1nformowania kleryków o nowych publikacjach z tej dziedziny 1 wskazywante na wartość 1 uzytecznośd poszozególnyoh pozycj1.

\section{b/ Pomoce dydaktyezne}

- Dobra mapa ozy mapy: często mozna je znaleźó w ksiegarniach/mapy produkcji NRD, np. Cesarstwa Rzymskiego/.

- Dó́wiadczenie uczy, ze stosowante środków audiowizualnych pozwala na lepsze zapamiętanie abstrakcyjnych treści poprzez wiazanie Ich z konkretnym obrazem, co daje dobre wynik1 dydaktyczne. Mozna w1ęc przy wykładzie patrologil uzywać diapozytywów miejsc zwiazanych z pisarzami /Antioch1a, Kapadocja/, kodeksów 1ch dzieł, miniatur, 1kon. Moga tu rómniez pomóc duze fotografie, kasety v1deo, płyty z muzyka liturgiozna krajów chrześcijańskiego Wschodu 1td. Stosowane rozsadnie 1 bez przesady, moga stworzy ć klimat przychylny dla nauczania patrologil.

$$
\text { Ks. Marek Starowieyski - Tarszawa }
$$

\section{ENSEIGNEMENT DE LA PATROLOGIE DANS LES SEMTNAIRES POLONAIS /Remarques d'un professeur de patrologie/ /Résumé/}

$L^{\prime}$ auteur décrit et charactèrise I'enseignement de la patrologie dans les séminaires de Pologne: le but, l'organisation des etudes, le programme et les methodes d enseignement, I'interdisciplinarité nécesşa1re et les dangers qui ménaçent l'enselgnement même, les qualités exigées de 1 enseignant, 1 'attitude des séminaristes à l egard de la patrologie et, enfin, les moyens didactiques employés ou qui peuvent servire pour, enselgner la patrologie. L'article remanie, va paraitre dans le numéro 13 du "Bulletin de Salnt-Sulpice" en 1987. 